\title{
Sorption of dissolved organic matter by freshwater bacterioplankton
}

\author{
Vladimir Tikhonov ${ }^{1 *}$, Olga Drozdova $^{2}$, Vladimir Cheptsov ${ }^{1}$ and Vladimir Demin ${ }^{1}$ \\ ${ }^{1}$ Lomonosov Moscow State University, Department of Soil Science, Moscow 119991, Russia \\ ${ }^{2}$ Lomonosov Moscow State University, Department of Geology, Moscow 119991, Russia
}

\begin{abstract}
Here we describe the study of the sorption of high-molecular components of dissolved organic matter (DOM) of natural waters - humic acids - by eight bacterial strains isolated from freshwater. Isotherms of DOM sorption by cells are described by the Langmuir equation. Grampositive bacteria adsorb more DOM than gram-negative bacteria, with high molecular weight DOM fractions binding in a relatively selective manner. A high positive correlation $(\mathrm{r}=0.91)$ was found between the decrease in the molecular weight of DOM during the sorption of these compounds by cells and the maximum sorption value. The formation of a polysaccharide capsule increases the binding of DOM by the cells of Pseudomonas sp. to the level of gram-positive bacteria.
\end{abstract}

\section{Introduction}

Dissolved organic matter (DOM) is a mixture of individual low molecular weight compounds, fulvic acids and humic acids (HAs), the latter being the most high molecular weight components of this system [1]. DOM in natural waters is a source of energy [2] and a regulator of physiological processes [3] for bacterioplankton. Bacteria are believed to consume mainly the low molecular weight labile DOM compounds, whereas the larger and more stable DOM compounds may play the role of biochemical regulators $[4,5,6]$. In the aquatic environment surrounding the cells of microorganisms, DOM compounds play the role of ligands capable of binding metal ions and xenobiotics into strong complexes, preventing them from entering living cells. The transfer of dissolved organic matter from the solution to the surface of the cells of microorganisms does not qualitatively change the situation, but only localizes these processes near the cell membranes [7].

Sorption of DOM by bacterial cells has earlier been studied on pure cultures of bacteria $[8,9,10]$. Gram-positive bacteria have been shown to adsorb 3-4 times more humic acids in comparison with gram-negative bacteria, but the strength of binding of HA molecules by gram-negative bacteria is 2-3 times higher [10]. The study of the sorption of DOM components on the microbiome isolated from freshwater reservoirs has shown the predominant sorption of high molecular weight fractions of DOM [11]. In general, however, the issue of the interaction of the DOM with the cells of microorganisms and the effect of the surface structure of the cell membranes of microorganisms on these processes

\footnotetext{
*Corresponding author: vvt1985@gmail.com
} 
remains poorly understood [12]. The aim of this work was to study DOM sorption by bacterial cells and DOM fractionation by bacteria with different cell surface structures.

\section{Materials and methods}

\subsection{Dissolved organic matter}

As a model of dissolved organic matter substance, we used humic acid CAS \# 1415-93-6 (Aldrich, USA) dissolved in 0.1 M phosphate-buffered saline, $\mathrm{pH}$ 7.0.

\subsection{Bacteria}

Water samples were collected from the natural waters of bogs, streams and the Mezha River in the Central Forest State Natural Biospheric Reserve (Tver Oblast, Russia). The site of sampling was pristine in terms of anthropogenic pollution. Six strains of bacteria were cultured on M001 nutrient agar (HiMedia Laboratories, India) and were identified as Pseudomonas spp., Bacillus sp., Acinetobacter lwoffii, Paenibacillus sp. and Oerskovia sp. according to 16S rRNA gene sequences as described previously [13]. Two more strains (Escherichia coli, Bacillus subtillis) were obtained from the Culture Collections of the Department of Soil Science, Lomonosov Moscow State University. Capsules of strains were identified microscopically by staining the preparations with ink.

\subsection{Isotherms of DOM sorption by bacterial cells}

Sorption of DOM onto bacteria was carried out according to the methods described in [10].

\subsection{Determination of molecular weights of DOM}

We used size-exclusion chromatography (SEC) performed by HPLC (Agilent 1100 with a diode array detector; Ultropac G2000SW column, LKB; eluent: $0.1 \mathrm{M}$ Na-phosphate buffer, $\mathrm{pH} 7.0$, supplemented with $0.1 \%$ SDS). The column was calibrated with a mixture of 12,500-65,000 Da globular proteins (Pharmacia, Sweden). The numerical average and weight average molecular weights were calculated using the standard method [14].

\section{Results}

\subsection{Isotherms of DOM sorption by bacterial cells}

The experimental values of DOM sorption by bacterial cells on the $\mathrm{Q}_{\mathrm{eq}} v s \mathrm{C}_{\mathrm{eq}}$ plots are close to L-type isotherms and are well approximated by the Langmuir equation (Fig. 1, 2). The average values of the coefficients $k$ (binding strength) and $\mathrm{Q}_{\max }$ (maximum adsorption) did not differ significantly for gram-positive and gram-negative bacteria, however, there was a tendency towards separation of these groups (Fig. 3). The value of maximum sorption $\left(\mathrm{Q}_{\max }\right)$ of DOM by bacterial cells lacking polysaccharide capsules ranged from 4$19 \mathrm{mg} \mathrm{DOM} / \mathrm{g}$ dry biomass for gram-negative bacteria to $21-162 \mathrm{mg} \mathrm{DOM} / \mathrm{g}$ dry biomass for gram-positive bacteria (Fig. 3, Table 1). The appearance of a polysaccharide capsule in Pseudomonas sp. results in an increase in sorption by 2.5 times. For gram-positive bacteria, we were not able to obtain a similar pair of strains, but high $Q_{\max }$ values $(517 \mathrm{mg} \mathrm{DOM} / \mathrm{g}$ dry biomass) in Paenibacillus sp. that were 3 times higher than the corresponding values in 
non-capsular forms of gram-positive bacteria suggest that in this case the appearance of a polysaccharide film also leads to an increase in the DOM sorption by bacteria.

The appearance of a polysaccharide film on the cell wall surface leads to a decrease (by almost 3 times) in the strength of DOM binding by the cells of Pseudomonas sp., in parallel with an increase in sorption; according to this parameter, the DOM sorption by a gramnegative bacterium approaches the sorption by a gram-positive cell of Paenibacillus sp. that is covered with a polysaccharide capsule $(\mathrm{k}=7)$.
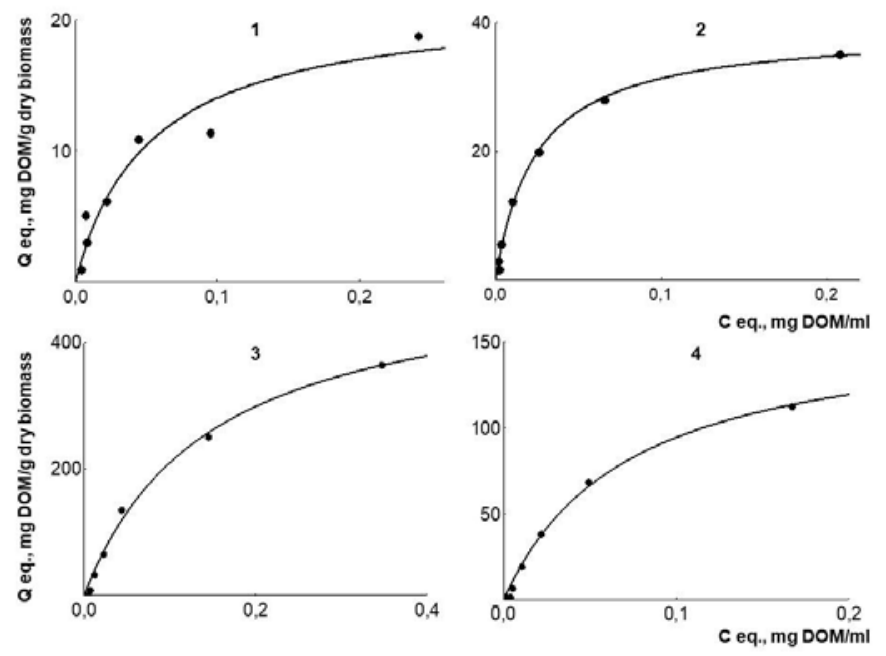

Fig. 1. Adsorption isotherms of DOM for gram-positive bacteria: Bacillus subtillis (1), Bacillus sp. (2), Paenibacillus sp. (3), Oerskovia sp. (4)
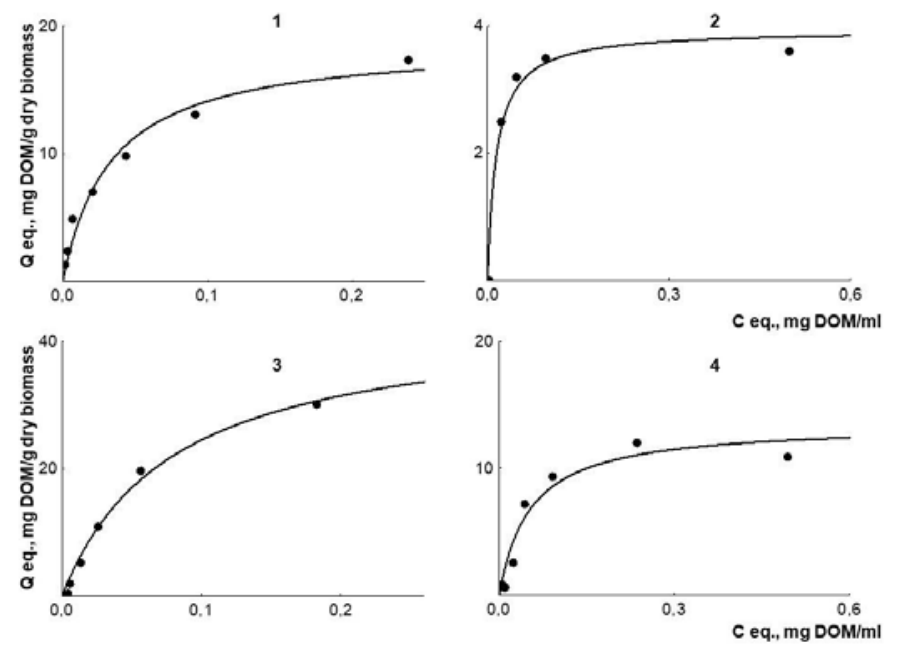

Fig. 2. Adsorption isotherms of DOM for gram-negative bacteria: Pseudomonas sp. (1), E. coli (2), Pseudomonas sp. with capsule (3), Acinetobacter lwoffii (4) 


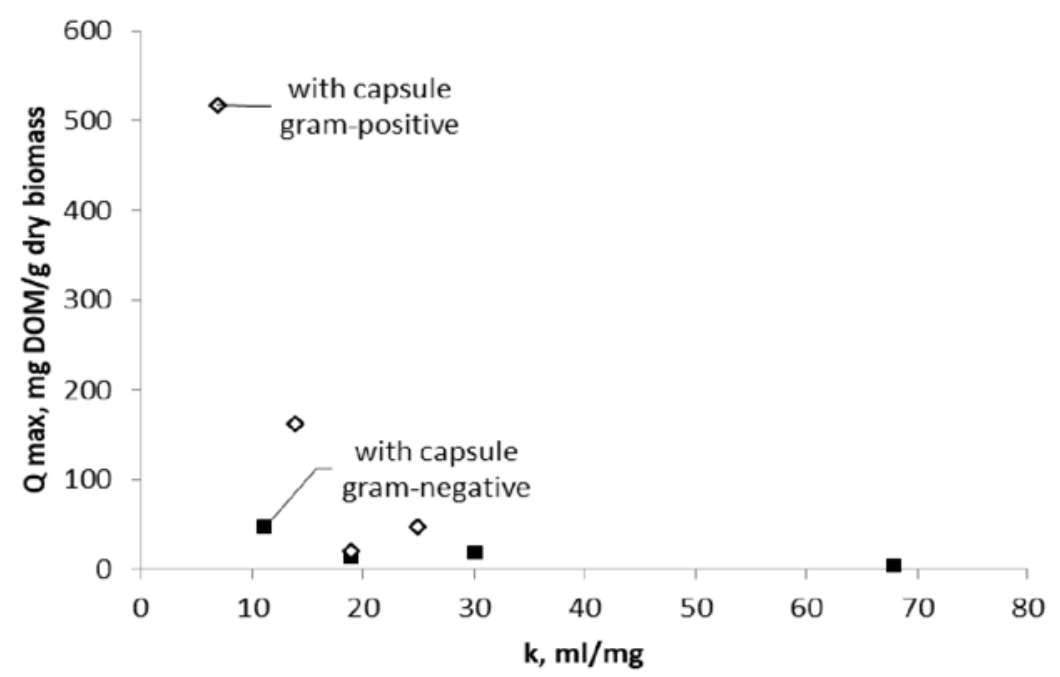

Fig. 3 Coefficients $Q_{\max }$ and $\mathrm{k}$ determined from the Langmuir equation for $\diamond$ - gram-positive and gram-negative bacteria

Table 1. Coefficients $\mathrm{Q}_{\max }$ and $\mathrm{k}$ determined from the Langmuir equation

\begin{tabular}{|c|c|c|}
\hline Strain & $\mathbf{k}$ & $\mathbf{Q}_{\max }$ \\
\hline Pseudomonas sp. (gram-) with capsule & 11 & 47 \\
\hline E. coli (gram-) & 68 & 4 \\
\hline Pseudomonas sp. (gram-) & 30 & 19 \\
\hline Acinetobacter lwoffii (gram-) & 19 & 14 \\
\hline B. sutilis (gram+) & 25 & 48 \\
\hline Bacillus sp. (gram+) & 19 & 21 \\
\hline Oerscovia sp. (gram+) & 14 & 162 \\
\hline Paenibacillus sp. (gram+) with capsule & 7 & 517 \\
\hline
\end{tabular}

\subsection{Weight average molecular weights and cell fractionation}

The average molecular weight of the original DOM was determined to be $12.2 \mathrm{kDa}$. The analysis of the molecular weight distribution of equilibrium DOM solutions by the SEC method was carried out for the points corresponding to the initial concentrations of HAs on the sorption isotherms $-0.05(0.1)$ and $0.5 \mathrm{mg} / \mathrm{ml}$. We accepted that the difference in weight average molecular weights can be considered significant if the difference between the value of this parameter before and after sorption by cells exceeds $10 \%$ (which corresponded to the mean value of the confidence interval for the replicates of the original DOM, alpha $=0.05$, replicates -11 ). The study showed that in 5 cases out of 8 there is a significant decrease in the molecular weight of DOM (Table 2). In other cases, the decrease in the weight average molecular weight of DOM during the sorption reaction can be viewed only as a trend. Differences in weight values are most noticeable at low DOM concentrations; the higher the DOM concentration in an equilibrium solution, the less noticeable the shift in the weight average molecular weights. The value of the maximum sorption of DOM for cultures lacking a capsule closely correlates (the correlation coefficient is 0.91) with the magnitude of the shift in the molecular weight in the range of DOM concentrations at which all active sites of adsorption on bacteria are saturated (Fig. 4). The appearance of a polysaccharide capsule in Pseudomonas sp. results in a sharp increase in the efficiency of HA fractionation (Fig. 5). 
Table 2. Decrease in molecular weight of DOM after incubation with bacteria

\begin{tabular}{|c|c|c|}
\hline Strain & $\begin{array}{c}\text { Decrease in molecular } \\
\text { weight of } 0.05(0.1) \\
\text { mg/ml DOM after } \\
\text { incubation, } \%\end{array}$ & $\begin{array}{c}\text { Decrease in } \\
\text { molecular weight of } \\
0.5 \mathrm{mg} / \mathrm{ml} \text { DOM } \\
\text { after incubation, } \%\end{array}$ \\
\hline \multicolumn{3}{|c|}{ Cultures not capable of fractionating DOM } \\
\hline Pseudomonas sp. & 5.5 & 5.5 \\
\hline Acinetobacter lwoffii & 7.3 & 7.3 \\
\hline Bacillus sp. & 3.3 & 3.3 \\
\hline \multicolumn{3}{|c|}{ Cultures capable of fractionating DOM } \\
\hline B. sutilis & 59.3 & 23.9 \\
\hline Oerskovia sp. & 34.7 & 34.7 \\
\hline E. coli & 11.0 & 1.2 \\
\hline Paenibacillus sp. (with capsule) & 27.7 & 18.5 \\
\hline Pseudomonas sp. (with capsule) & 74.4 & 32.7 \\
\hline
\end{tabular}

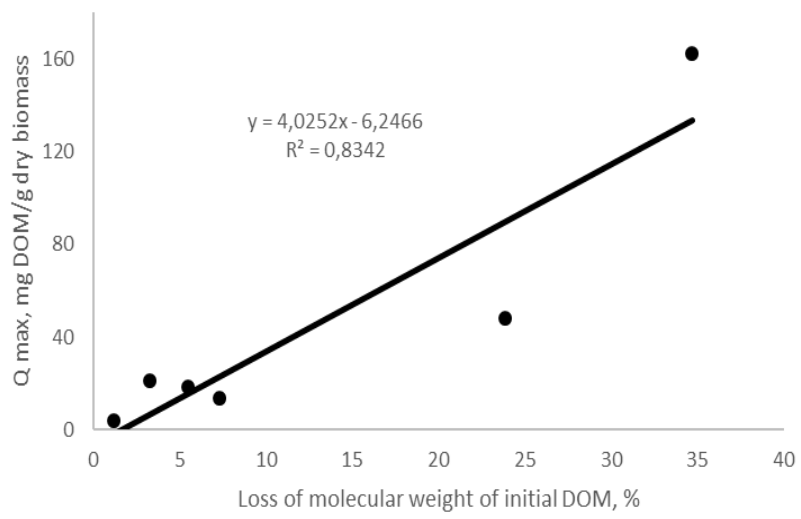

Fig. 4 Correlation between $Q_{\max }$ and decrease in molecular weight of initial DOM after incubation with bacteria lacking capsules

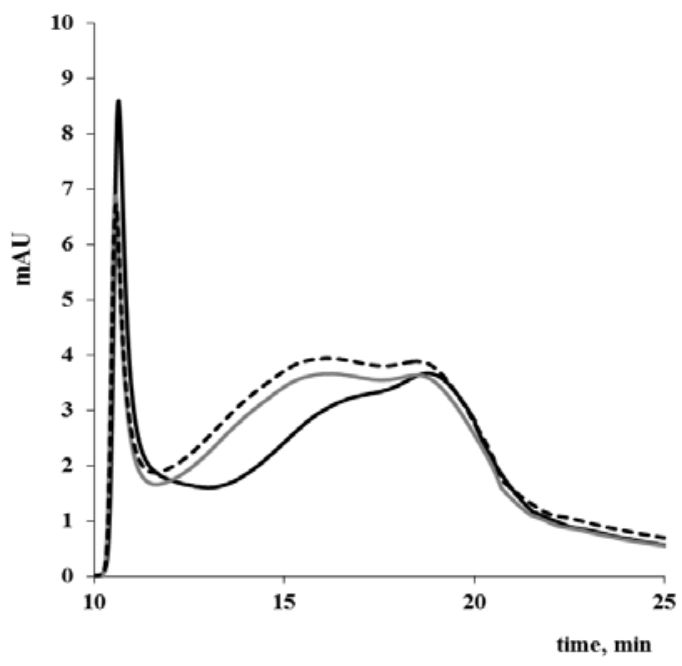

Fig. 5 Chromatogram of the initial DOM (dotted line), after sorption by the cells of Pseudomonas sp. without (grey line) and with capsule (black line) 


\section{Discussion}

The preferential sorption of high molecular weight DOM fractions has previously been found in the microbial heterotrophic community of freshwater reservoirs in Canada [11], $B$. subtils culture [15], and minerals [16]. This is most likely due to the larger number of active binding sites of a different nature in molecules of high molecular weight DOM fractions than in molecules of low molecular weight fractions, which provides a greater number of point contacts with active centers on the cell surface (in the cell wall or polysaccharide layer) and thus increases the thermodynamic stability of forming surface complexes.

Modification of the bacterial cell surface by DOM components has important ecological consequences, since it leads to changes in the parameters of the sorption of metals and other substances by microorganisms $[17,18]$ and, accordingly, to changes in the bioavailability of these substances for cells [7], as well as to an increase in the resistance of microorganisms to UV radiation or bacteriophages [19].

The research was funded by the Russian Science Foundation (Grants No. 18-74-00088 (isolation and identification of bacteria) and 19-77-00017 (sorption and determination of molecular weights of DOM)).

This research was performed according to the Development program of the Interdisciplinary Scientific and Educational School of M.V.Lomonosov Moscow State University «Future Planet and Global Environmental Change »

\section{References}

1. E.Thurman, Organic geochemistry of natural waters (Springer, Netherlands.1985)

2. K. Docherty, K. Young, P. Maurice, S. Bridgham, Microb. Ecol., 52, 378 (2006)

3. A. Anesio, C. Hollas, W. Grane'li, J. Laybourn-Parry, Appl. Environ. Microbiol., 70(8), 4848 (2004)

4. L. Zou, X. Wang, J. Callahan, R. Culp, R. Chen, M. Altabet, M. Sun, Limnol. Oceanogr., 49(1), 297 (2004)

5. V. Tikhonov, A. Yakushev, Yu. Zavgorodnyaya, B. Byzov, V. Demin, Euras. Soil. Sci., 3, 305 (2010)

6. V.Tikhonov, Yu. Zavgorodnyaya, B. Byzov, V. Demin, Eur. J. Soil Biol., 75, 47 (2016)

7. V. Demin, V. Terentev, Yu. Zavgorodnyaya, Humic Compounds in the Biosphere. Proc. 2nd Int. Conf., 37 (2004)

8. J. Fein, J. Boily, K. Glüclu, E. Kaulbach, Chem. Geol. 162, 33 (1999)

9. P. Frost, P. Maurice, J. Fein, Chem. Geol. 200, 217 (2003)

10. V. Tikhonov, D. Orlov, O. Lisovitskaya, Yu. Zavgorodnyaya, B. Byzov, V. Demin. Microbiology 82(6), 707 (2013)

11. K. Young, P. Maurice, K. Docherty, S. Bridgham, Geomicrobiol J., 21, 521 (2004)

12. N. Kulikova, I. Perminova, G. Badun, M. Chernysheva, O. Koroleva, E. Tsvetkova, Appl. Environ. Microbiol. 76 (18), 6223 (2010)

13. A.Belov, V.Cheptsov, E.Vorobyova, AIMS Microbiol., 4(4), 68 (2018)

14. Jan. F. Rabek, Experimental methods in polymer chemistry (Wiley, New York, 1980)

15. P. Maurice, M. Manecki, J. Fein, J. Schaefer, Geomicrobiol. J., 21, 69 (2004)

16. Q. Zhou, P. Maurice, S. Cabaniss, GCA, 65, 803 (2001) 
17. H. Du, W.Chen, P.Cai, X. Rong, K. Dai, C. Peacock, Q. Huang, Q. Sci. Rep. 6, 194 (2016)

18. O. Drozdova, O. Pokrovsky, S. Lapitskiy, L. Shirokova, A. González, V. Demin, J. Colloid Interface Sci. 434, 59 (2014)

19. V.V. Tikhonov, SUITMA9 Congress, 177 (2017). 